\title{
Enhancing Heritage and Traditional Architecture Conservation Through Digital Technologies. Developing a Digital Conservation Handbook for As-Salt, Jordan
}

\author{
Claudia Trillo ${ }^{1(\bowtie)}\left(\mathbb{D}\right.$, Rania Aburamadan ${ }^{2}$, Chika Udeaja ${ }^{3}$, \\ Athena Moustaka ${ }^{1}$, Kwasi Gyau Baffour ${ }^{1}$ (D), \\ and Busisiwe Chikomborero Ncube Makore $^{1}$ (D) \\ ${ }^{1}$ University of Salford, Salford, UK \\ C.Trillo2@salford.ac.uk \\ 2 Amman Arab University, Amman, Jordan \\ ${ }^{3}$ London South Bank University, London, UK
}

\begin{abstract}
Heritage cities are facing unprecedented pressure, due to the combination of climate change impacts, rapid urbanization and uncontrolled growth. Historic urban centres in Middle East and North Africa (MENA) countries are particularly exposed. This paper discusses the benefit of applying digital technologies, and in particular Building Information Modeling (BIM), in supporting heritage conservation, by developing a proof of concept based on a purposely chosen case study, i.e. the traditional Jordanian city of As-Salt near Amman. Building on and moving forward the tradition of paper-based Conservation Handbooks for historic cities, this study aims at exploiting the potential of digital technologies for enhancing the development and implementation of Digital Conservation Handbooks. Documentation and promoting of As-Salt will be conducted through developing a set of virtual models (3D models and BIM objects) suitable to support the construction sector and traditional architecture and heritage, framed and delivered in form of Digital Conservation Handbook. This will be achieved by: developing a new set of BIM (Building Information Modeling) objects related to the traditional architecture heritage in Jordan, suitable to be used by engineers and architects in the development of interventions on the built environment; creating a library of 3D models of exemplar buildings (Jordan heritage and traditional architecture), suitable to be used to promote the tourist image of Jordan. This will set a precedent for further documentation and heritage conservation of traditional cities in Jordan, MENA countries and internationally. Finally, the paper will discuss issues and challenges of documenting traditional heritage and architecture in As-Salt and the impact that such process may achieve in raising awareness across the local communities, thus offering insights to the larger community of architects, conservationists, and planners.
\end{abstract}

Keywords: Heritage conservation $\cdot$ Conservation handbooks $\cdot$ Heritage and BIM 


\section{Conservation of Historic Centres and Conservation Handbooks: Opportunities for Digital Technologies}

Heritage cities are facing unprecedented threats. While almost unanimous consensus exists internationally on the need of safeguarding monuments and key-tangible heritage assets for the benefit of future generations, less relevant heritage assets, such as traditional housing, vernacular architecture, historic urban patterns and features, historic artefacts related to socio- economic systems, struggle to be adequately acknowledged and protected. UNESCO's recommendation on the Historic Urban Landscape (UNESCO 2011) describes the need for a shift from an emphasis on architectural monuments primarily towards a broader recognition of the importance of the social, cultural and economic processes in the conservation of urban values. Pressures on historic urban areas encompass rapid urbanization, uncontrolled growth, environmental issues related to the climate change impact on cities. Tools for managing successfully historic urban landscape conservation include participatory tools for engaging stakeholders and citizens, knowledge and planning tools, regulatory systems and financial tools (Bandarin and Oers 2012; UNESCO 2016).

This study aims at producing a novel tool positioned within the interplay between community engagement and knowledge and planning tools, by building on and moving forward the existing tradition of the Italian Conservation Handbooks (Giovanetti 1992). Digital technologies, and in particular BIM (Building Information Modelling), are instrumental to update the traditional approach pursued by the Conservation Handbooks and exploit the potential of digital technologies in heritage conservation. There is therefore a need of focus on the implementation of conservation policies, integrating management, conservation, development, and planning disciplines to practice. Indeed, implementing conservation policies is obviously challenging, since effective conservation requires alignment of policies and instruments at different level, adequate resources and availability of skills and competences (Ginzarly et al. 2019). The abovementioned tradition of "Conservation Handbook" stems from the pioneering experience developed in 1977 in the city of Pesaro (Panella 1992). In this city, local government was seeking to implement the local plan for the historic centre, and was struggling to implement effective conservation of the urban fabric. Resulting in a dedicated city laboratory, supported by experts and conservationists. The experience let to the creation of a handbook, offering technical support to architects and conservations, which at the same time acting as vehicle for raising awareness across residents about the value of heritage assets.

Based on this pioneering experience, the City of Rome replicated the methodology, between 1982 and 1984 thanks to the support given from the University La Sapienza and experts of the caliber of Paolo Marconi. At that time, the famous architect Carlo Aymonino was councilor for the historic centre and enabled synergies with the university course on reuse of historic buildings directed by Giovannetti (Panella 1992). A final case of reference which fully developed this methodology is the handbook prepared for the city of Citta' di Castello, which spans between 1980s and early 1990s (Giovanetti 1992). These cases supported the development and testing of a now consolidated methodology for the conservation of historic urban fabric, based on the three 
specific goals: (1) encourage and steer the conservation of historic urban fabric, through appreciation of the materiality of historic buildings; (2) offer technical insights to conservations and architects; (3) engage with the communities on the conservation of traditional heritage. In fact, once exemplar cases become "models" to look at, following the publication of the handbooks, residents acknowledged the value of those buildings and a virtuous process of value recognition and historic buildings appreciation emerged. Eventually, conservation handbooks became indirectly instrumental to raising awareness and proud with locals.

Over the years, this methodology has been replicated and led to the production of a robust body of knowledge on the traditional characters of historic architectures in different regions of Italy. The rationale beyond the conservation handbooks lies at the interplay between micro, meso and macro scale. Conservation of the character of the urban fabric is enabled by the effective conservation of the buildings, which are made of different elements, such as roofs, windows, floors, walls. The articulation of some selected exemplar buildings through their own components, allows depiction of the key-elements for the thorough understanding and appreciation of the materiality of the historic fabric. Each handbook offers therefore a selection of case studies, extracted from some selected exemplar buildings and showing the material details of the city by means of its components. While creating technical knowledge, the handbook also works in the interplay between society (community recognizing values) and economic fabric (workers capable to perpetuate the technique), perpetuating the concept that historic urban fabric and landscape are outcomes of the socio- economic place- based fabric (Turri 2001).

Nowadays digital technologies offer a unique opportunity for uplifting the power of the rationale beyond conservation handbooks. In facts, they offer the possibility to integrate multiple layers of information and to link across industry, community and higher education with a flexibility and timeliness that traditional techniques such as paper-based drawings did not allow at such an extent (Udeaja et al. 2019). In particular, Building Information Modelling (BIM) offers the opportunity to link a variety of information concerning heritage assets and convey them across multi-disciplinary professionals (Pocobelli et al. 2018). This is a process also known as Heritage Building Information Modelling (HBIM). Therefore, the researchers developed a project hypothesis rethinking conservation handbook in the context of digital technologies. It is based on the idea that contemporary conservation handbook should take the form of BIM models, embedding key features of historic buildings whilst enabling designers to gather and reassemble information easily (Volk et al. 2014). This facilitates the conservation of historic centres, both through an enhanced body of knowledge made available to the local professionals' community, and through community engagement.

\section{Research Methodology}

This study aims at showing the potential of an application of digital technologies to the conservation of historic centre, by channelling BIM into the tradition of the conservation handbook. Digital handbooks based on BIM objects will facilitate the preparation and delivery of conservation projects in historic centres, and at the same time 
will contribute to raise awareness across the local community about the importance of such heritage. At this goal, this study discusses the application of this methodology through a demonstrator project, i.e. the BIM Conservation Handbook for the City of As-Salt, in Jordan. Thanks to a Royal Academy for Engineering British grant, a team of UK and Jordan based architects and academics are developing a BIM based Handbook for the conservation of the historic architecture of the city of As-Salt, Jordan. This city has been chosen because it holds great importance as heritage and traditional architecture, whose conservation is currently threatened because of abandonment and decay. The planning office showed interest in collaborating with the team of academics and demonstrating the viability of the hypothesis, hence the team decided to pursue this collaboration since engagement with local stakeholders was necessary for developing the demonstrator.

An action research approach was adopted for this study. Action research involves an iterative process approach in which the action researcher and a client collaborate in the diagnosis of the problem and in the development of a solution based on the diagnosis (Bryman 2012; Bryman and Bell 2011). This type of research is facilitated by participation and collaboration of number of individuals with a common purpose. In this case, the researchers are collaborating with the office "Project Development Unit" (in charge of delivering the UNESCO application for inscription) of the city of As-Salt to re-adapt the traditional handbook for heritage conservation by implementing digital technologies. Action research is chosen in order to introduce improvements in urban heritage conservation practices in As-Salt. This paper sets up the preliminary studies for undertaking the demonstrator, which will be developed in a second phase of this research. Establishing the context for the selection of the exemplar buildings and clarifying the steps for the development of the demonstrator are the preliminary steps covered by this study. Further investigation and empirical data collection will conclude this study.

\section{As-Salt: Supporting Historic Urban Landscape Conservation Through Digital Technologies}

The City of Al-Salt is situated in Jordan as shown in Fig. 1. It was the Jordan capital city in 1922 and it is located West of Amman, along the way connecting Amman to Jerusalem (ASCOP 2016). The unique atmosphere of Al-Salt heritage city is mainly due to its late XIX century residential buildings. Historic houses were built two or three floors, elegantly decorated with columns, balconies and vaults. These houses are very peculiar because they were built in a local yellow stone, extracted from caves close to the city. This stone is extremely tough and resistant, however, negligence and lack of care from residents and local authorities let them perish to the point that the heritage centre is now in decay. The population is growing but locals prefer to invest in modern buildings rather than caring about the historic ones, thus, nowadays many buildings are in a bad state and need repair. Moreover, attempts to exploit the potential of tourism development by city beautification proved to be fragmented and superficial (Khirfan 2013). 
In the 1990s, an in-depth analysis of the urban fabric was conducted by initiative of the Salt Development Corporation, such studies were brought forward leading to a systematic understanding of the level of integrity and protection of the historic centre. However, despite efforts made to document and steer the conservation of the historic fabric, still Fakhoury and Haddad (2017) found that severe and rapid urban change is noticeable and planning policies do not properly address heritage values. Thus, leading to the destruction of image and authenticity of significant areas in the historic core. On the other hand, traditional architecture included in the historic fabric holds the potential to hit sustainability targets (ASCOP 2016; Almatarneh 2013). Amongst the various examples of historic buildings, in As-Salt, the team focused on chosen sub-case studies based on the following criteria: (1) availability of data survey and (2) being the building exemplar of a recurrent constructional and typological tradition, rather than unique.

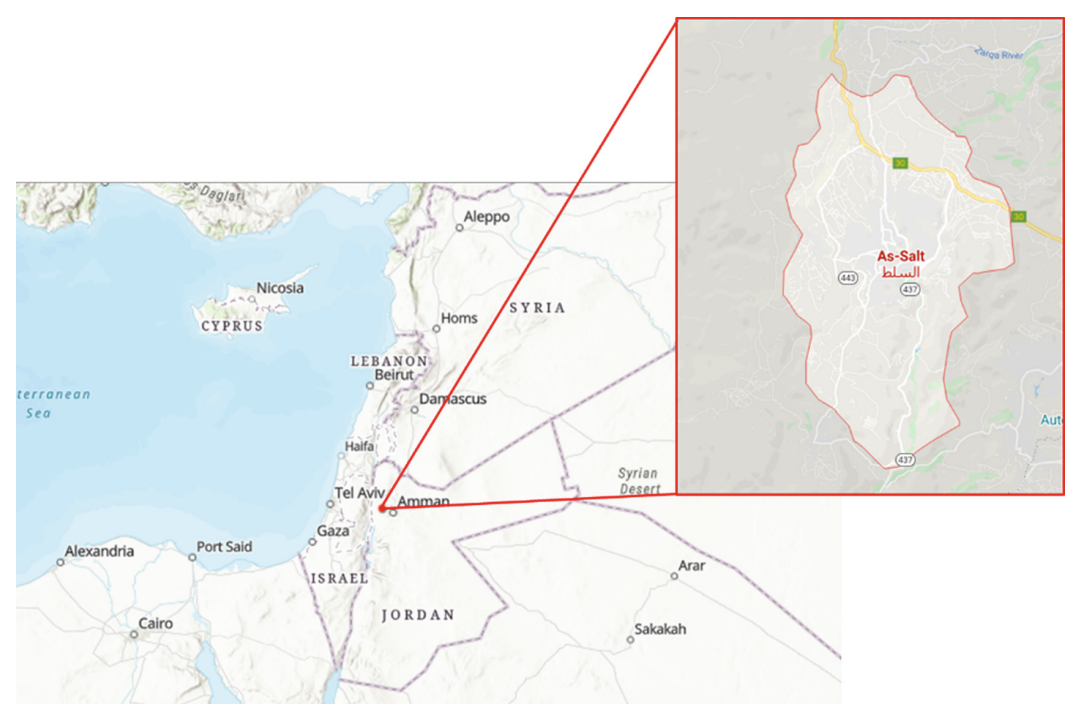

Fig. 1. As-Salt, Jordan (Source: ArcGIS modified by authors)

\section{Case Study Preliminary Development: Qaqish House}

The Qaqish house is one of the oldest notable residences in Al-Salt which currently serves as the office of As-Salt's City Development Project (ASCOP 2016). Restoration of the Qaqish house was conducted in two phases: 1989 to 1993 and in 2000 by the owner Basem Eid Qaqish. The Qaqish house is characterized as an extended family home transformed into a merchant house, with numerous traditional features such as a cross-vaulted entrance, stone walls and arched windows (Fig. 2). The project team conducted on field observation and direct survey on the Qaqish house and is producing 
BIM objects, by identifying relevant architectural elements inside and outside the house, including doors, windows, arches, stairs, façade decorative features. The team has selected sample BIM objects that are repetitive in the traditional architecture of AsSalt (cross- vault, stone wall, arched windows). A new library of BIM objects derived by the Qaqish house will be developed for future conservation works. BIM objects will include details of materials used such as stone, mortar, wood.

As a result, documentation of the house is necessary to start working on BIM objects. This can be achieved through several software such as AutoCAD and Autodesk Revit. The project used Autodesk Revit for documentation and the researchers obtained laser scan drawings for the house with collaboration with As-Salt municipality as shown in Fig. 3. The use of 3D Laser scanning for heritage assets is an ideal technology for BIM due to its effectiveness, accuracy, and high level of detail (Barazzetti et al. 2015; Beraldin 2004). 3D Laser scanning accurately documents as built settings and real environment and can also be used for reality capture and augmented reality in many aspects of architecture and engineering. The previous drawings of 3D laser scan will be inserted into Revit, and all details of the house will be listed as library inside Revit. In this regards, the role of BIM is to link all information relating to the Qaqish house and combining it to produce a comprehensive a 3D model and as BIM has to rely on different software to collect this information for a project and compile it together (Sztwiertnia et al. 2019; Garagnani and Manferdini 2013). Revit is one of the BIM software to create BIM model. It combines the architectural design, structural engineering for coordination. Also, it helps in making a data-rich (library) model based on the contributions. Such a model of the house will be a rich based of information about each detail inside and outside the house for any circumstances and as first step of combining tradition, heritage and technology.

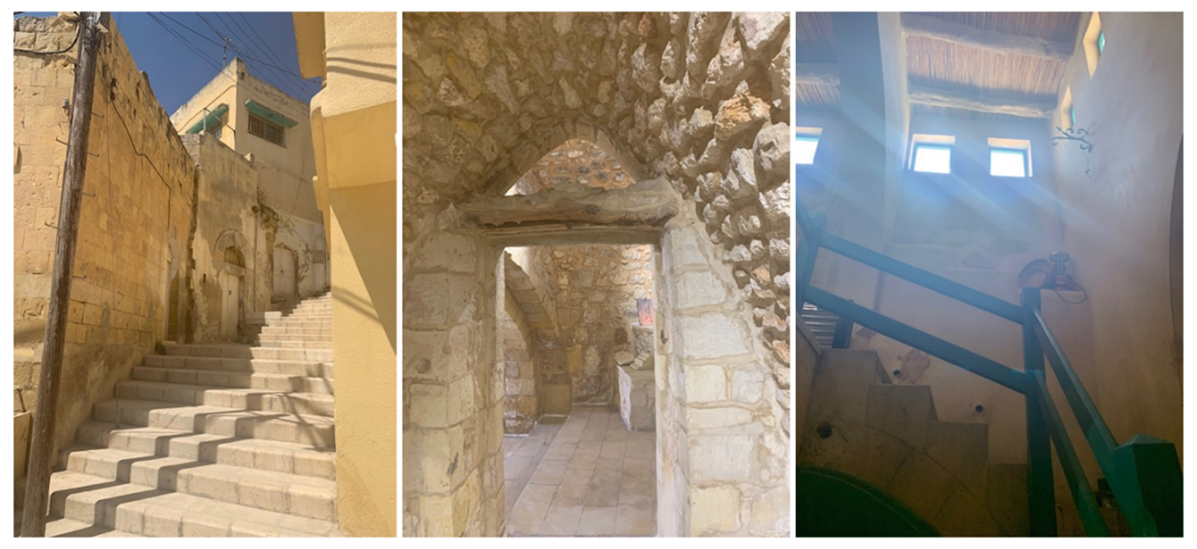

Fig. 2. Interior features of Qaqish House (Source: Authors) 

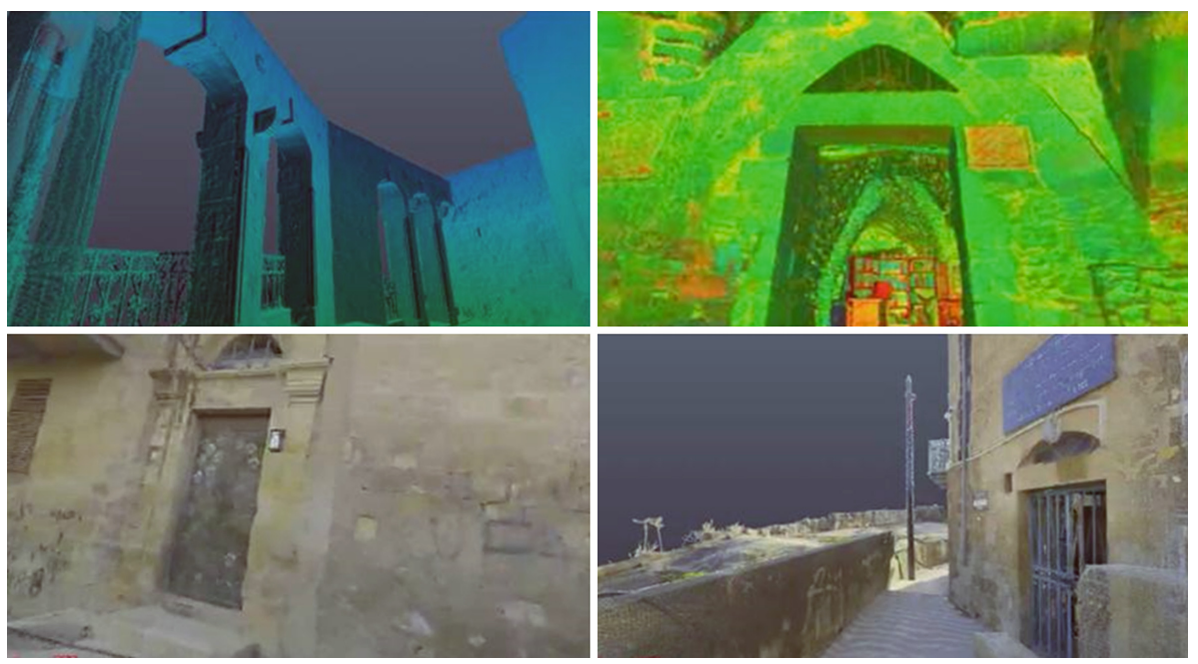

Fig. 3. 3D laser scanning for Qaqish house (Interior \& exterior features) (Source: Authors)

\section{Conclusions}

This paper presented the preliminary studies undertaken by UK and Jordanian team of academics, seeking to build and move forward the tradition of Conservation Handbook by implementing digital technologies and turning traditional paper-based Conservation Handbooks in digital toolkits for designers and conservationists. This will be achieved by developing a proof of concept in Jordan, made possible by a grant awarded to the team by the Royal Academy of Engineering. The proof of concept will consist of a sample chapter for a Digital Conservation Handbook for the city of As-Salt. Moreover, the proof of concept will allow development that will be used to test the impact of such an innovative and digitally based Conservation Handbook on local communities. Furthermore, the implementation of this project will be used to raise awareness across residents on the value of traditional historic buildings in As-Salt. BIM is a wellestablished process to optimize the building process with many benefits such as avoiding issues of conflict, reworking and duplication whether in offices or on a construction site. However, using BIM in heritage conservation is a still a novel opportunity of using BIM in terms of documentation, urban reservation and sociocultural criteria. Another opportunity is creating concrete connection between components of building design, environment, construction site, social elements, and economical issues. In order to achieve accuracy, data is captured and inserted about the morphology of the house and the surrounding and the contexts have to be surveyed using high definition technologies (point clouds) which are state of art for preservation of elements, complemented by fieldwork and direct observation. Digital technologies are used to check on structural preservation and for studies about technological building systems over architecture history period. In conclusion, the BIM process allows data to be collected, combined and inserted from engineering perspectives into 
other tools to make it available for researchers, experts and generic actors involved in heritage means. The use of BIM that will be tested in this case study is innovative, because it will be related to the aim of creating a digital conservation handbook on traditional historic buildings in As-Salt. It is expected that as a result of such a study, engagement with local planners and residents will raise awareness on the importance of valuing the conservation of the historic centre of As-Salt. Furthermore, the testing will allow for the development of a proof of concept for a BIM based conservation handbook. Thus, perpetuating this tradition through the instruments of digital technologies.

\section{References}

Almatarneh, R.T.: Sustainability lessons learnt from traditional architecture: a case study of the old city of As-Salt, Jordan. IOSR-JESTFT 5(3), 100-109 (2013)

ASCOP. Architectural Heritage in As-Salt City, Jordan. Retrieved from As-Salt, Jordan (2016)

Bandarin, F., Oers, R.: The Historic Urban Landscape: Managing Heritage in an Urban Century. Wiley-Blackwell, Chichester (2012)

Barazzetti, L., Banfi, F., Brumana, R., Gusmeroli, G., Previtali, M., Schiantarelli, G.: Cloud-toBIM-to-FEM: structural simulation with accurate historic BIM from laser scans. Simul. Model Pract. Theor. 57, 71-78 (2015). https://doi.org/10.1016/j.simpat.2015.06.004

Beraldin, J.-A.: Integration of laser scanning and close-range photogrammetry - the last decade and beyond. Int. Arch. Photogramm. Remote Sens. 35, 972-983 (2004)

Bryman, A.: Social Research Methods. Oxford University Press, Oxford (2012)

Bryman, A., Bell, E.: Business Research Methods. OUP, Oxford (2011)

Fakhoury, L.A., Haddad, N.A.: Aspects of the architectural and urban heritage: from registers to conservation for adaptive and modern use at the historic cores of salt and Irbid, Jordan. Archnet-IJAR 11(2), 190-218 (2017). Accessed from https://archnet.org/publications/12018

Garagnani, S., Manferdini, A.M.: Parametric accuracy: building information modelling process applied to the cultural heritage preservation. Int. Arch. Photogram. Rem. Sens. Spat. Info. XL (5), 87-92 (2013). https://doi.org/10.5194/isprsarchives-xl-5-w1-87-2013

Ginzarly, M., Houbart, C., Teller, J.: The Historic Urban Landscape approach to urban management: a systematic review. Int. J. Heritage Stud. 25(10), 999-1019 (2019). https://doi. org/10.1080/13527258.2018.1552615

Giovanetti, F.: The Conservation Handbook for the city of Citta' di Castello. In: Giovanetti, F. (ed.) Manuale del Recupero di Citta' di Castello, pp. 17-48. Edizioni DEI Tipografia del Genio Civile, Rome (1992)

Khirfan, L.: Ornamented facades and panoramic views: the impact of tourism development on alsalt's historic Urban landscape. In: Gharipour, M. (ed.) International Journal of Islamic Architecture, vol. 2, pp. 307-324. Intellect, Bristol (2013)

Panella, R.: In support of a conservation- driven approach in the reuse of historic architecture. In: Giovanetti, F. (ed.) Manual for the Recovery of the Town of Citta di Castello. DEI Editions, Civil Engineering Typography, Rome (1992)

Pocobelli, D.P., Boehm, J., Bryan, P., Still, J., Grau-Bové, J.: BIM for heritage science: a review. Heritage Sci. 6(1), 30 (2018). https://doi.org/10.1186/s40494-018-0191-4

Sztwiertnia, D., Ochałek, A., Tama, A., Lewińska, P.: Conservation, analysis, and restoration HBIM (heritage Building Information Modell) of the Wang Stave Church in Karpacz -Case Study. Int. J. Arch. Heritage 1-15 (2019). https://doi.org/10.1080/15583058.2019.1645238 
Turri, E.: Il Paesaggio Come Teatro. Marsilio, Venezia (2001). Accessed from http://www. marsilioeditori.it/catalogo/libro/3176865-il-paesaggio-come-teatro

Udeaja, C., et al.: Scientometric analysis and mapping of digital technologies used in cultural heritage field. Paper presented at the ARCOM 2019, UK (2019)

UNESCO. The UNESCO Recommendation on the Historic Urban Landscape (2011). Accessed from Paris, France: https://whc.unesco.org/uploads/activities/documents/activity-638-98.pdf

UNESCO. The HUL guidebook. Paper presented at the 15th World Conference of the League of Historical Cities, Bad Ischl, Austria (2016)

Volk, R., Stengel, J., Schultmann, F.: Building Information Modelling (BIM) for existing buildings-literature review and future needs. Autom. Constr. 38, 109-127 (2014). https:// doi.org/10.1016/j.autcon.2013.10.023

Open Access This chapter is licensed under the terms of the Creative Commons Attribution 4.0 International License (http://creativecommons.org/licenses/by/4.0/), which permits use, sharing, adaptation, distribution and reproduction in any medium or format, as long as you give appropriate credit to the original author(s) and the source, provide a link to the Creative Commons license and indicate if changes were made.

The images or other third party material in this chapter are included in the chapter's Creative Commons license, unless indicated otherwise in a credit line to the material. If material is not included in the chapter's Creative Commons license and your intended use is not permitted by statutory regulation or exceeds the permitted use, you will need to obtain permission directly from the copyright holder.

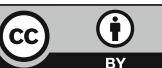

